\title{
Application of Three-Dimentional Computerized Tomographic Angiography in the Planning of Pterional Scalp Incision to Preserve the Superficial Temporal Artery
}

\author{
Süperfisiyal Temporal Arteri Korumak için Pterional Skalp Insizyonunda \\ ÜçB Boyutlu Bilgisayarlı Tomografik Anjiyografinin Kullanılması
}

Enis KURUOGLU, Cengiz COKLUK, Abdullah Hilmi MARANGOZ, Kerameddin AYDIN

Ondokuz Mayis University, School of Medicine, Department of Neurosurgery, Samsun, Turkey

Corresponding Author: Enis KURUOGLU / E-mail: drenis@hotmail.com

\begin{abstract}
A standard pterional scalp incision is commonly used in the surgical treatment of lesions located at the cranial base. There is a close relationship between the superficial temporal artery and a pterional scalp incision. Standard pterional scalp incision is widely used in the aneurysm surgery of the basal cerebral arteries. Three-dimensional computerized tomographic angiography (3D CT Angiography) using the three-dimensional (3D) volume rendering technique is commonly used in the neuroradiological diagnosis of intracranial aneurysms. 3D CT Angiography produced for the mentioned purpose may concomitantly be used without any additional investigation for the imagination of superficial temporal artery. Virtual skin incision may be done in the computer software under the illumination of data obtained from the 3D CT Angiography. In this study, we investigated the applicability of this technique using 3D CT Angiography. In conclusion, using this technique in cases undergoing surgery with standard pterional scalp incision may preserve thesuperficial temporal artery leading to the prevention of the skin problems originating from insufficient blood supply, and allowing the use of the preserved superficial temporal artery for cranial anastomosis surgery in the future. KEYWORDS: Pterional scalp incision, Pterional craniotomy, Superficial temporal artery
\end{abstract}

öz

Standart pterional skalp insizyonu, kafa tabanında lokalize lezyonların cerrahi tedavisinde sıklıkla kullanılmaktadır. Standart pterional skalp insizyonu ile süperfisiyal temporal arter arasında yakın bir ilişki vardır. Standart pterional skalp insizyonu, bazal serebral arterlerin anevrizma cerrahisinde yaygın bir şekilde kullanılmaktadır. Üç boyutlu hacim oluşturma tekniği kullanılarak yaratılan 3D bilgisayarlı tomografik anjiyografi (3D BT Anjiyografi) kranial anevrizmaların nöroradyolojik tanısında yaygın olarak kullanılmaktadır. Süperfisiyal temporal arterin görüntülenmesi için hastaya ilave bir tetkik kullanılmayarak, tragus bölgesinde superfisial temporal arterin seyri ve dalları 3D BT Anjiyografi kullanılarak net bir şekilde gösterilebilmektedir. Sanal cilt insizyonu, 3D BT Anjiyografiden elde edilen veriler ışığında bilgisayar programında tamamlanabilir. Çalışmada, 3D BT Anjiyografi kullanılarak tekniğin uygulanabilirliği araştırıldı. Sonuç olarak; bu teknik kullanılarak süperfisiyal arterin korunması ile kan kaybından kaynaklanan cilt problemleri önlenebilir ve korunmuş süperfisiyal temporal arter kullanılarak gelecekte muhtemel kranial anastomoz ameliyatlarında kullanılabilirliğine olanak sağlanmış olur.

ANAHTAR SÖZCÜKLER: Pterional skalp kesisi, Pterional kraniotomi, Süperfisiyal temporal arter

\section{INTRODUCTION}

Pterional craniotomy was described and popularized by Yasargil $(9,10)$. It is commonly used in the surgery for cranial base and basal cerebral arteries $(7,9,10)$. A standard curvilinear pterional skin incision is used for pterional craniotomy $(2,6,7$, $9,10)$. In the performing of standard pterional skin incision, a point 1 or 1.5 centimeter in front of the tragus and the crossing point at the hairy scalp and a perpendicular line drawn from the ipsilateral midpupil is the ending and starting point of the skin incision respectively $(9,10)$. The curvilinear line drawing between these two points staying inside the hairy skin is described as standard pterional skin incision $(9,10)$.
The superficial temporal artery is one of the external carotid artery branches and it is the main feeders of the scalp. It passes in front of the tragus and divides into its terminal branches. It is recommended to protect and dissect the superficial temporal artery as much as possible when performing of pterional skin incision for pterional craniotomy $(9,10)$.

3D CT Angiography is a noninvasive imaging modality and is commonly used in the cases with subarachnoid hemorrhage $(1,4,5,8)$. Superficial temporal artery and its branches may be imaged using computer software program named athes 3D volume rendering technique intended for imaging of basal cerebral arteries (3). The data obtained from these images may be used for the planning of standard pterional skin incision 


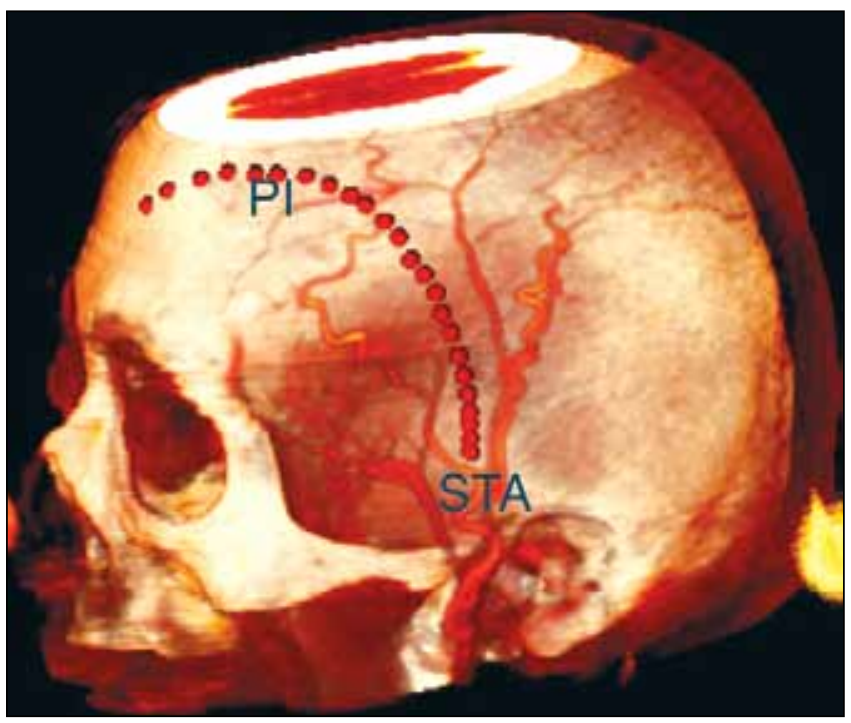

Figure 1: Pterional skin incision and the superficial temporal artery are shown in this figure (PI: pterional incision, STA: superficial temporal artery.

in the protection of superficial temporal artery. On the other hand, these images may be used in the understanding of the surgical anatomy of the artery and its variations and help its dissection and preservation. In this report, the feasibility and importance of the 3D CT Angiography created by using the $3 \mathrm{D}$ volume rendering modality is emphasized in patients with a cerebral aneurysm.

\section{OPERATIVE TECHNIQUE}

3D CT Angiography that was performed in an illustrative case with subarachnoid hemorrhage for imaging the basal cerebral artery by using 3D volume rendering technique is evaluated for the imaging potential of the superficial temporal artery. For this purpose, the use of the DICOM images obtained from a spiral computerized tomography was transferred to a software program (OsiriX MD) previously installed in a MacBook pro computer was used in the creation of $3 D \mathrm{CT}$ Angiography by using 3D volume rendering technique. In these images, the starting point of the skin incision and its curvilinear course, and the ending point in front of the tragus were virtually dotted (Figure1). The locations of the superficial temporal artery in front of the tragus, branching, and the main branch was determined. The superficial temporal artery was clearly visualized in the obtained images. In these images, the main branch of the artery and the location of the incision in front of the tragus and the point superior to the zygomatic arch may be estimated.

\section{DISCUSSION}

Pterional craniotomy popularized by Yasargil is commonly used in the surgical treatment of aneurysms located at the basal cerebral arteries $(9,10)$. It is not only limited with aneurysm surgery and at the same time it can be used for the surgical treatment of the lesions located at the cranial base. The length of the skin incision should be adequate for performing appropriate pterional craniotomy $(9,10)$. The ending and starting point of the standard skin incision for pterional craniotomy can be described as the point of 1 or 1.5 centimeter in front of the tragus and the crossing point at the hairy scalp and perpendicular line drawn from the ipsilateral midpupil respectively $(9,10)$. The incision is continued curvilinear between these two points as it stays in the hairy skin $(2,6,7,9,10)$. It is possible that the marking of the third point between these two points in the making easy curvilinear skin incision. The incision ending at the inferior point in front of the tragus according to the anatomical course of the superficial temporal artery in this region is important.

The superficial temporal artery crosses in front of the tragus after emerging from the external carotid artery and ends with its terminal branches. It is one of the main arteries supplying the scalp. It is extremely important to preserve the superficial temporal artery to avoiding problems originating from the insufficient blood supplying to the scalp. This artery may be injured during the skin incision performing for the pterional craniotomy. In avoiding this injury, 3D CT angiography used in the cases with subarachnoid hemorrhage for the diagnosing of the aneurysm may be used for the imaging of superficial temporal artery and further the planning of the skin incision can be done.

The planning of skin incision can safely be done through the determination of superficial temporal artery course and its relationship with the tragus and zygomatic arc by using OsiriX MD software program. The use of this technique in the case undergoing surgery with standard pterional scalp incision can preserve the superficial temporal artery leading to the prevention of the skin problems originating from insufficient blood supply, and allow the use of preserved superficial temporal artery for probable cranial anastomosis surgery in the future.

\section{CONCLUSION}

The course of superficial temporal artery and its branching in the tragus-zygomatic arc region may be imagied with 3D CT Angiography created by using the $3 \mathrm{D}$ volume rendering technique. The planning of skin incision can be done according to these images for preserving this artery. It was concluded that the preserving of this artery might prevent the problems originating from the insufficient blood supply of the skin. On the other hand, it also allows the using of this preserved artery in possible future cranial by-pass surgery if the patient needs it.

\section{REFERENCES}

1. Amagasaki K, Takeuchi N, Sato T, Kakizawa T, Shimizu T: Current usage of three-dimensional computed tomography angiography for the diagnosis and treatment of ruptured cerebral aneurysms. Journal of Clinical Neuroscience 11: 481-485, 2004 
2. Chao SC, Shen CC, Cheng WY: Microsurgical removal of sylvian fissure lipoma with pterion keyhole approach-case report and review of the literature. Surgical Neurology 70: 85-90, 2008

3. Chen JQ, Guan Y, Li G, Li XH, Zhan YF, Li XY, Nie L, Han XJ: Application of 3D computed tomography angiography technology in large meningioma resection. Asian Pac J Trop Med 5(7):577-581, 2012

4. Hwang SB, Kwak HS, Han YM, Chung GH: Detection of intracranial aneurysms using three-dimensional multidetectorrow CT angiography: Is bone subtraction necessary? European Journal of Radiology 79: e18-e23, 2011

5. Kato Y, Sano H, Katada K, Ogura Y, Hayakawa M, Kanaoka N, Kanno T: Application of three dimensional CT angiography (3D-CTA) to cerebral aneurysms. Surgical Neurology 52: 113-122, 1999

6. Miyazawa T: Less invasive reconstruction of the temporalis muscle for pterional craniotomy: Modified procedures. Surg Neurol 50: 347-351, 1998
7. Ogilvy SC, Crowell RM, Heros RC: Surgical management of middle cerebral artery aneurysms: Experience with transsylvian and superior temporal gyrus approaches. Surg Neurol 43: 15-24, 1995

8. Siablis D, Kagadis GC, Karamessini MT, Konstantinou D, Kamabatidis D, Petsas T, Nikiforidis GC: Intracranial aneurysms: Reproduction of the surgical view using 3D-CT angiography. European Journal of Radiology 55: 92-95, 2005

9. Vishteh AG, Marciano FF, David CA, Baskin JJ, Spetzler RF: The pterional approach. Operative Technique in Neurosurgery 1: 39-49, 1998

10. Wen HT, Oliveira E, Tedeschi H, Andrade FC, Rhoton AL: The pterional approach: Surgical anatomy, operative technique and rationale. Operative Technique in Neurosurgery 4: 60-72, 2001 